\title{
LATVIJAS LAUKSAIMNIECĪBAS UN MEŽSAIMNIECĪBAS PRECES STARPTAUTISKAJĀS TIRGUS PLŪSMĀS 21. GADSIMTĀ
}

\author{
Antons Berjoza \\ Latvijas Universitāte, G̦eogrāfijas un Zemes zinātṇu fakultāte, \\ e-pasts: antons.berjoza@inbox.Iv
}

\begin{abstract}
Anotācija. Rakstā aplūkota Latvijas starptautiskā tirdzniecība laikā no 2000. līdz 2016. gadam. Tiek aplūkotas vairākas nozares, kas ir būtiskas lauksaimniecības un mežsaimniecības precēm. Latvijas starptautiskā tirdzniecība ir ḷoti daudzveidīga un tai ir vairākas tendences, kuras aplūkotas, lai aprakstītu un izskaidrotu preču plūsmas no un uz Latviju.

Autors veica starptautiskās tirdzniecības ǵeogrāfijas statistisku analīzi, izmantojot relatīvā biežuma vērtēšanas metodi un nosakot stabilākos Latvijas eksporta tirgus. Kā datu avots izmantota Latvijas Centrālas statistiskas pārvaldes detalizētā ārējās tirdzniecības statistika. Piegādes biežuma statistiskā būtiskuma noteikšanā tika izmantota Fišera transformācija.

Pētījuma laikā tika definēti Latvijai svarīgākie tirgi gan ES iekšienē un ārpus tās, gan tirgi, ar kuriem Latvijai ir stabilas, laika gaitā pārbaudītas ekonomiskās saites, kā arī ieskicētas uzṇēmēju iniciatīvas aplūkotajā periodā, lai iekḷūtu jaunajos tirgos. Kopumā rakstā ir parādīta frekvenču metodes pielietojamība ārējās tirdzniecības statistiskajā analīzē un iegūto rezultātu interpretācija, ņemot vērā Latvijas un citu valstu ekonomiskos parametrus.

Atslēgas vārdi: eksports, imports, datu analīze, piegādes biežums.
\end{abstract}


Ievads

Ārējā tirdzniecība ir vien̄̄gais veids, kā valsts piedalās starptautiskajā darba dalīšanā. Lai saprastu ārējās tirdzniecības tendences, zinātniskajā literatūrā analizēti lielākie tirdzniecības partneri (Berentsen 2012; Kantar et al. 2011 u.c.), veikta preču apgrozījuma analīze (Birzins 2004; Keišs u.c. 2009; Devaeva 2006 u.c.), analizēti importēto/eksportēto preču veidi vai grupas, (Berentsen 2012; Gingrich 2011; Devaeva 2006 u.c.). Ārējā tirdzniecība ir viens no būtiskiem valsts ekonomikas elementiem, ko obligāti jāietver ikvienas valsts ǵeogrāfiskajā aprakstā, jo tas parāda valsts integrāciju pasaules ekonomikā, vietu darba dalīšanas procesā un globalizācijas līmenī, kā arī ekonomisko efektivitāti.

Latvijas ārējā tirdzniecība ir attīstījusies gan kā neatkarīgas Latvijas valsts elements, gan kā citu valstu reǵionāls subjekts. Vēsturiski Latvijas ārējā tirdzniecība ir cieši saistîta ar tranzīttirdzniecību un lauksaimniecības preču eksportu. Mūsdienās šī tendence joprojām ir aktuāla, tomēr vairumā ekonomisku un politisku faktoru dēḷ notiek pārmaiņas, arī mūsu tirdzniecības struktūrā.

Zinātniskajā literatūrā šis aspekts arī ir attēlots. Latvijas, Eiropas un pasaules zinātnieki pēta starptautisko tirdzniecību un veic tās ietekmējošo faktoru analīzi. Ir vērts aplūkot dažus darbus, kuri ir līdzīgi šī raksta tēmai. Nacionālajā mērogā raugoties, ir vairākas publikācijas, piemēram, viena ekonomiskā sektora ietvaros (Bertaite, Liepa 2011); citi orientējas uz nacionālo līmeni (Jenkins 2014; Lemoine 2010; Kaminski, Raballand 2009; Rocha et al. 2009; Hall 2006) vai paplašina mērogu līdz reǵionālajam līmenim, lai izpētītu regiionālās tendences starptautiskajā tirdzniecībā (Berentsen 2012; Coulibaly, Fontagne 2006; Tsygankov 2000; Mack, Jacobson 1996) vai tirdzniecību reǵionālajā (Bajo-Rubio, Diaz-Roldan 2012; Tsygankov 2000) un starpreǵionālajā (Birzins 2004) līmen̄i. Lielākais mērogs starptautiskās tirdzniecības izpētē ir globālais līmenis, kurā ir iespējams atrast visdažādāko izpētes tematiku: globālas starptautiskās tirdzniecības reǵionālie (Edwards 2007; Herekenrath 2007) vai nacionālie (Jenkins 2014; Barton, Murray 2009) aspekti; pētnieki akcentē globālas starptautiskās tirdzniecības vispārīgajām problēmām, piemēram, globalizāciju (Ellis 2007; Herekenrath 2007; Birzins 2004), ražošanas kompleksu izvietošanu (Birtchnell 2013. Brulhart 1998), kā arī vienkāršāku tēmu - valstu ekonomiskā attīstība atkarībā no to tirdzniecības saitēm (Haibo 2004) vai vispārīgām vietas/izvietojuma likumsakarībām (Guerin 2006). İpaši interesanti ir globālās starptautiskās tirdzniecības pētījumi, kas veikti analītiskās statistikas ǵeogrāfijā (Krugman 2009; Edwards 2007; Poon et al. 2000; Mack, Jacobson 1996; Grant 1994), kuros aplūkoti un analizēti konkrēti gadījumi un lielas statistiskas datu kopas, kas apraksta globalizācijas un starptautiskās tirdzniecības procesus un notiekošās pārmaiņas.

\section{Materiāli un metodes}

Darbā tika izmantoti Centrālās statistiskas pārvaldes apkopotie dati par Latvijas eksportu harmonizētās preču aprakstīšanas un kodēšanas sistēmas 4 zīmju kodā laika periodā no 2000. līdz 2013. gadam. Latvijas eksporta dati par katru mēnesi tika 
sarindoti pēc valstīm visa perioda griezumā. Šādi izveidota izejas datu matrica tika pārveidota binārā formā. Ja kādā mēnesī eksporta piegādes noteiktajā preču grupā uz konkrēto valsti notika, tad attiecīgajā matricas šūnā tika norādīta vērtība 1 , ja eksporta piegādes nenotika, tad konkrētajā matricas šūnā tika norādīta vērtība 0 . Rezultātā tika iegūti eksporta piegāžu biežuma rādītāji katrai preču grupas datu kopai un katrai valstij. Plašāk relatīvā biežuma vērtēšanas metodes izmantošanu ǵeogrāfiskos pētījumos ir aplūkojis Paiders (2008), bet metodes ierobežojumus - Krastiņš un Ciemiņa (2003). G̣enerālās kopas biežums tika salīdzināts ar katras valsts biežumu, izmantojot Fišera transformāciju (Fisher, Yates 1963):

$$
\begin{gathered}
\text { (1) } \varphi=\frac{2 \pi}{180} \arcsin (\sqrt{p}) \\
\varphi \text { - Fišera funkcijas vērtība, ja p ir biežums } \\
\mathrm{T}-\text { statistika tika aprēķināta, dalot Fišera funkciju (generālajai kopai un }
\end{gathered}
$$
attiecīgajai valstij) vērtību starpību ar brīvības pakāpju lieluma koeficientu (Krastiņš, Ciemiņa 2003). Rezultātā ir iespējams iegūt relatīvo biežumu eksportam uz jebkuru valsti, pēc kura var spriest, cik liela ir varbūtība, ka vienā uz labu laimi izvēlētā mēnesī tiks veikta eksporta piegāde uz attiecīgo valsti. Pēc t - statistikas aprēķināšanas, pieņemot, ka būtiskuma slieksnis ir ar $95 \%$ ticamību, valstis tika iedalītas 3 grupās:

1) valstis, uz kurām Latvijas eksporta varbūtība ir statistiski būtiski augsta (ja Tempīiskais bija lielāks par 2, bet nozares vidējais eksporta piegāžu biežums bija mazāks par eksporta piegāžu vidējo biežumu attiecīgajā valstīi);

2) valstis, uz kurām Latvijas eksporta varbūtība ir statistiski būtiski zema (ja Tempīriskais bija lielāks par 2, bet nozares vidējais eksporta piegāžu biežums bija lielāks par vidējo eksporta piegāžu biežumu attiecīgajā valstī, pie šīs grupas ir arī pieskaitāmi rezultāti, ar kuriem eksports uz attiecīgo valsti vispār nav noticis un ir vienāds ar nulli);

3) valstis, uz kurām Latvijas eksportam ir gadījuma raksturs (ja T- empīriskais bija mazāks par 2, jo šādā gadījumā, ņemot vērā darbā izvirzītos būtiskuma kritērijus, nav iespējams noraidīt nulles hipotēzi).

\section{Rezultāti un diskusija}

Analizējot starptautiskās tirdzniecības saites, izvēlētajās nozarēs ir manāmas vairākas likumsakarības, kuras parasti novēro un uzsver ekonomikas zinātne un lietišķās zinātnes/nozares, kas ir tieši saistītas ar tirdzniecības procesu. Pirmkārt, preču tirdzniecības distance - piemērots attālums, uz kuru transportēt preci realizācijai ir ekonomiski izdevīgi; otrkārt, mērḳvalstu ekonomiskā struktūra - ekonomiski attīstītas un mazāk attīstītas nozares, to darbaspēka ietilpība un tehnoloǵiskais līmenis; treškārt, ražoto preču nomenklatūra - ir svarīgi apzināties, ka dažas valstis būs mazāk ieinteresētas importēt kādu preci, ja tājā tiek ražotas analogas preces. 


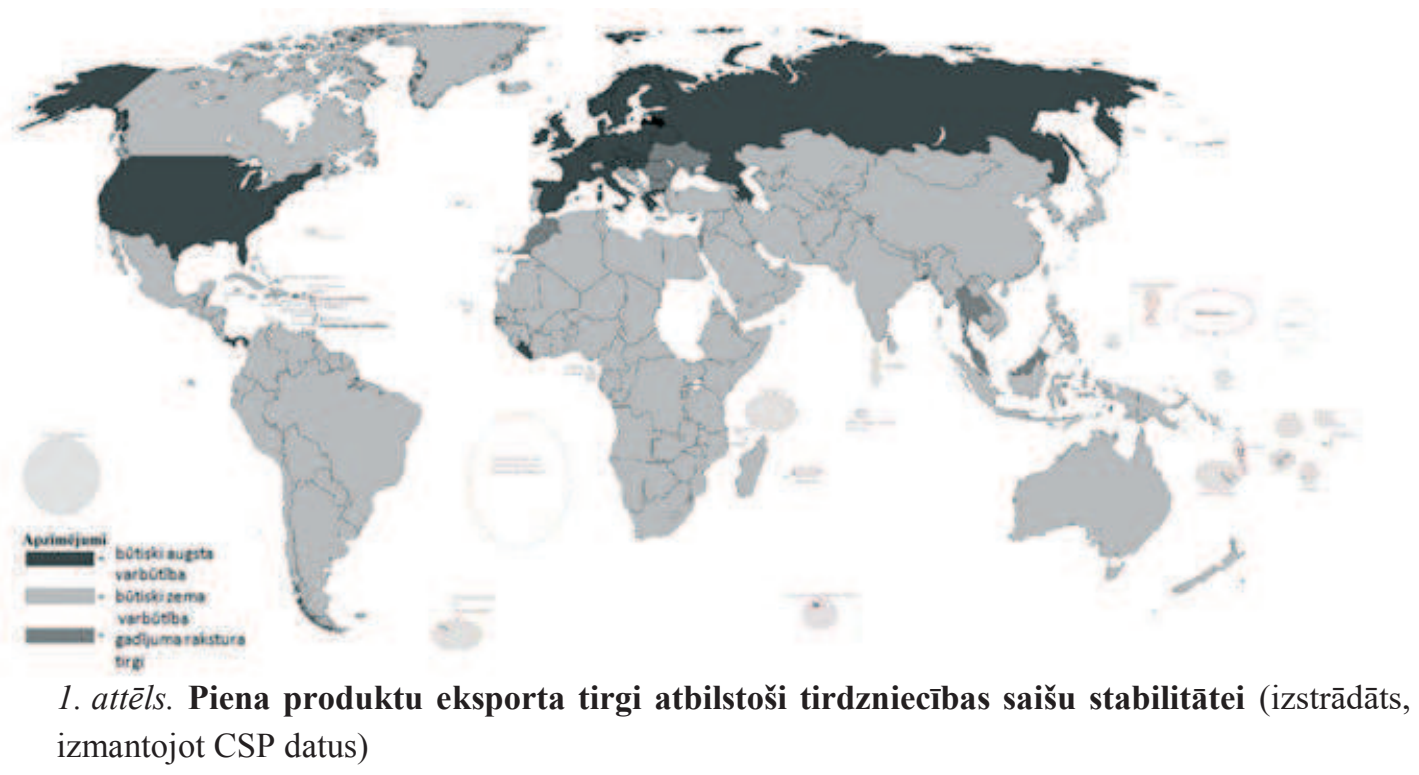

Aplūkojot iegūtos rezultātus, šīs likumsakarības ir labi manāmas vairāku preču vai preču grupu telpiskajā attēlojumā. Piemēram, gaḷas produktu grupā Latvijas tirdzniecībā dzīvo dzīvnieku kategorija ir telpiski ierobežota, nepārsniedzot Eiropas Savienības, Baltijas valstu robežas. Līdzīgi svaigas gaḷas un filejas kategorija svarīga ir distance, kuru kravas var sasniegt 1-2 dienu laikā. Palielinot preču glabāšanas ilgumu, t.i., ceḷot to sasaldēšanas pakāpi, palielinās arī distance. Dzesēti produkti jau tiek tirgoti visā ES teritorijā un pat vairākās Austrumeiropas un Āzijas valstīs, bet sasaldēti produkti tiek piegādāti jau tālākajos pasaules regionos. Pārstrādātu produktu kategorijās ir vērojamas līdzīgas tendences - ja gaḷas un zivju izstrādājumi parasti tiek tirgoti ES un tuvākajās valstīs, tad konservētiem produktiem ir vairāk iespēju nonākt tirdzniecībā pat citos pasaules reǵionos.

Viens no labi vizualizējamiem piemēriem minēto tirdzniecības tendenču raksturošanai ir piena produkti, jo to sadale ir izteikta atbilstoši glabāšanas ilgumam svaigiem produktiem ne ilgāk kā 7 dienas, pārējiem līdz pat dažiem gadiem. Aplūkojot 1. attēlu, ir redzams, ka kopumā gan austrumu, gan rietumu virziens ir aktuāls Latvijas tirdzniecībā. Ir noteiktas atšķirības tirdzniecības struktūrā, bet kopumā var novērot, ka Baltijas jūras reǵionā notiek intensīva tirdzniecība ar visiem piena produktiem. Austrumu virzienā notiek svaiga piena un tā tiešās pārstrādes produktu tirdzniecība, bet rietumu virzienā tiek tirgoti pārstrādāti piena produkti, piemēram, siers un biezpiens. Šāds preču plūsmu sadalījums ir izskaidrojams ar protekcionisku ES dalībvalstu nostāju pret lauksaimniecības preču ražotājiem, būtībā mākslīgi pazeminātas piena cenas neveicina Latvijas produktu eksportu uz ES rietumu valstīm. ES austrumu dạ̦ā gan tirdzniecība ir ḷoti aktīva, īpaši pierobežu regionos. Ar pārstrādes produktiem ir atšķirīga situācija, jo siers ir izteikti lokāls produkts un tam ir tūkstošiem variāciju, kas sekmē jaunu un mazāk zināmu produktu importu valstīs, kur siers ir iecienīts produkts. Sviests ir Latvijas zīmols lauksaimniecības produktu eksportā, tāpēc tam ir pozitīva reputācija Eiropā. 


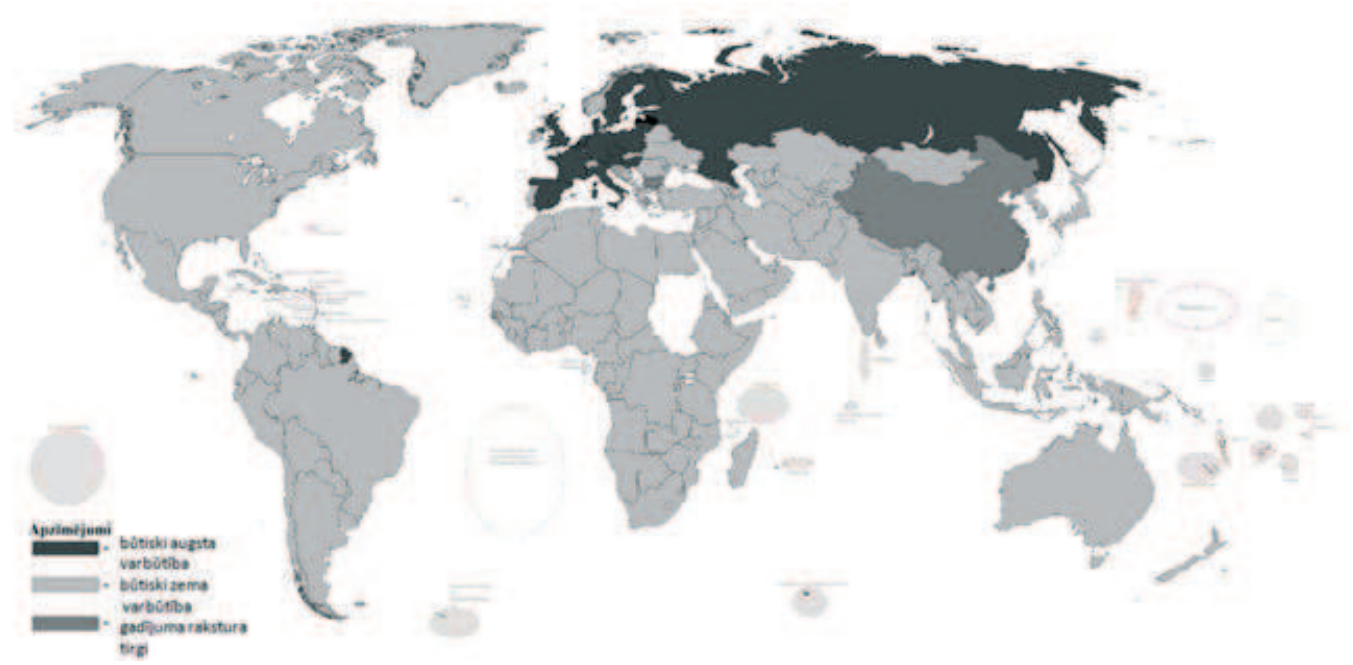

2. attēls. Piena produktu importa tirgi atbilstoši tirdzniecības saišu stabilitātei (izstrādāts, izmantojot CSP datus)

2. attēlā ir parādīta importa tirgus aina, kurā var pamanīt pārmaiņas. Pirmkārt, ir izteikta austrumu-rietumu robeža, kas arī lielā mērā sadala preču importu. No tuvākajām valstīm un austrumiem tiek ievests svaigs piens, sviests un piena pārstrādes produkti, bet no rietumiem pārsvarā dārgas, luksusa klases piena preces un produkti, īpaši siers, jogurti un citi izstrādājumi.

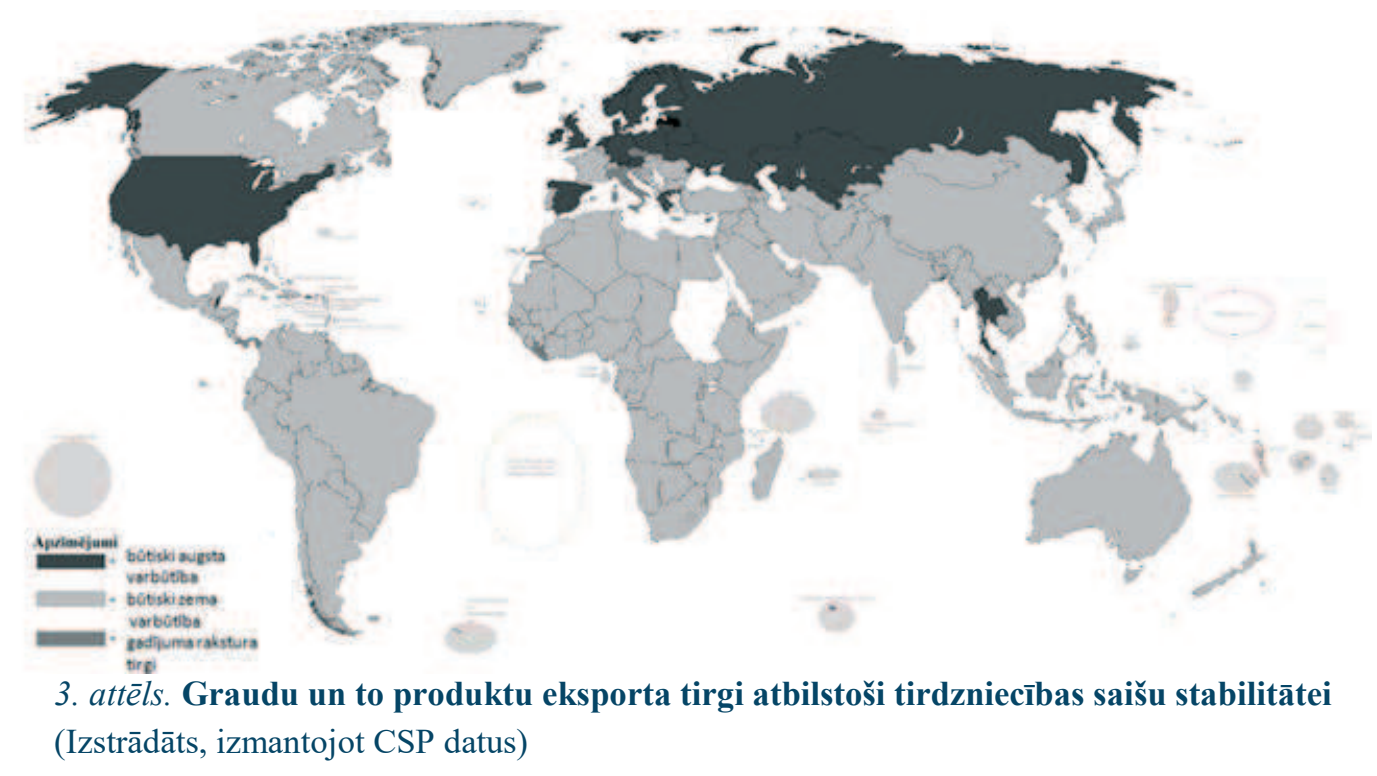

Viens no svarīgiem šī pētījuma elementiem ir alternatīvas metodes izmantošana, lai vērtētu nevis tirdzniecības apjomu, ko parasti izsaka miljonos Eiro vai svarā, bet gan tirdzniecības saišu stabilitāti un ekonomiskās mijiedarbības ciešumu, izmantojot frekvenču metodi. 1. attēlā ir redzams, kā, neraugoties uz to, ka Austrumeiropas valstis ir būtiski tirdzniecības partneri, dažas no tām ir atzīmētas atšķirīgi. Tas liecina, ka ne visas valstis, ar kurām Latvijai aplūkojamajā periodā ir bijušas ekonomiski aktīvas attiecības, ir stabili tirdzniecības partneri, dažreiz aktivitātes ir nosacītas, īpaši preču 
kategorijās, kurās partneriem nav attīstìtas mijiedarbības un tie ir tiešie konkurenti, piemēram, Eiropas tirgū.

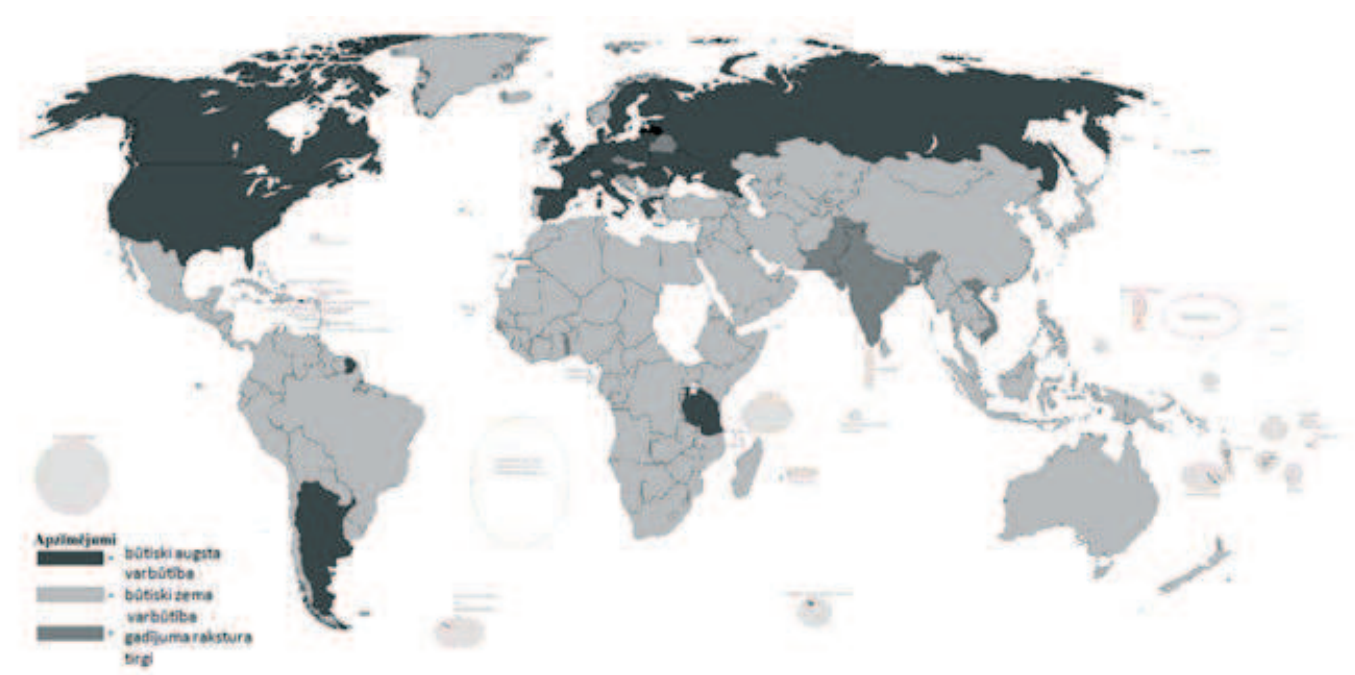

4. attēls. Graudu un to produktu importa tirgi atbilstoši tirdzniecības saišu stabilitātei (izstrādāts, izmantojot CSP datus)

Nākamie 2 attēli (3., 4. attēls) attēlo graudu un to produktu eksportu un importu, kas pirmajā gadījumā ir l,oti raksturīgs piemērs minētajām metodologiskajām atšķirīiām. Eksports no Latvijas pēc apjomiem apskatāmajā periodā lielākoties bijis uz Dienvidu valstīm -Spāniju, Grieķiju un Itāliju, kā arī Ėǵipti, Lībiju, Alžīiiju, Irānu u.c. Savukārt, 3. attēlā stabilie tirdzniecības partneri ir citas valstis. Kāpēc pazūd lieli graudu importētāji no Āzijas un Āfrikas, bet ES importētāji paliek? Jāapzinās, ka ES dalībvalstis ar savu labi attīstīto ceļu un sakaru tīklu var iepirkt nepieciešamo preču daudzumu jebkurā brīdī, bet Āzijas un Āfrikas valstis to dara vienreiz gadā, lielā daudzumā un epizodiski, kas nosaka to, ka šīs saites, lai gan svarīgas, nav pastāvīgas un stabilas.

Svarīgi apzināties, ka kopumā lauksaimniecības un mežsaimniecības sektors, būdams svarīgs tirdzniecības aktivitātes dalībnieks, nav vienīgais ražojošais sektors, un mūsdienu postindustriālajā ekonomikā tas nav svarīgākais, tomēr ir atkarīgs gandrīz tikai no vietējiem resursiem, kas nozīmē to ietekmi cilvēku apziṇā, domājot par veiksmīgu saimniecisko darbību.

\section{Secinājumi}

Jāsecina, ka Latvijas starptautiskā tirdzniecība apskatāmajā periodā un preču kategorijās ir bijusi aktīva un daudzveidīga.

Ir novērotas vairākas tendences, kas savieno un arī sadala būtiskus Latvijas tirdzniecības partnerus Eiropā, Austrumos un Rietumos. Var nošķirt tuvo preču apritē loku ar visblīvākajām preču plūsmām - Baltijas jūras reǵions un Krievija; vidējo aprites reǵionu - ES, Ziemeḷāfrika, Centrālā Āzija un Transkaukāza valstis; un tālāko loku pārējo pasauli. Preču plūsmu abos virzienos nosaka ekonomiskā situācija tirgos, partnervalstis un arī sektoru struktūra, kas raksturo pieprasījumu un veido tirdzniecības konfigurāciju. 


\section{Literatūras saraksts}

Bajo-Rubio, O., Diaz-Roldan, C. (2012). Do exports cause growth? Some evidence for the new EU members. Post-Communist Economies, 24(1), 125 - 131.

Barton, J.R., Murray, W.E. (2009). Grounding Geographies of Economic Globalisation: Globalised spaces in Chile's non-traditional export sector, 1980-2005. Tijdschrift voon Economische en Sociale Geografie, 100 (1), 81 - 100.

Berentsen, W.H. (2012). The Change in European Foreign Trade from 1960 to 2010: A Geography of Leading Merchandise Exporting Partners. Eurasian Geography \& Economics, 22 (3), 380 - 399.

Berjoza, A., Paiders, J. (2013). Geographical trends in export market of Latvian Fisheries production. Research for Rural Development. International Scientific Conference, 2, 208 - 214.

Bērtaite, L., Liepa, I. (2011). Analysis of tree felling, regeneration, import and export dynamics in Latvia. Research for Rural Development. International Scientific Conference, 2, 13 - 16.

Birtchnell, T. (2013). Fill the ships and we shall fill the shops: the making of geographies of manufacturing. Area, 45(4), $436-442$.

Birzins, A. (2004). Bilateral diplomatic and economic relations between East Asia and the new EU members: The case of Latvia. Asia Europe Journal, 2 (2), 221 - 235.

Brulhart, M. (1998). Economic Geography, Industry Location and Trade: The Evidence. The World Economy, 21(6), 775 - 801.

Coulibaly, S., Fontagne, L. (2006). South-South Trade: Geography Matters. Journal of African Economies, 15(2), 313 - 341 .

Devaeva, E. (2006). Foreign Trade Flow Structure of the Russian Far East. Far Eastern Affairs, 34(3), 93-105.

Edwards, T.H. (2007) How globalized really is European Trade? In: Spatial Economic Analysis, Vol. 2, No. 3, pp. 259-280.

Ellis, R.D. (2007). Paths to foreign markets: Does distance to market affect firm internationalisation? International Business Review, 16 (5), 573 - 593.

Gingrich, S. (2011). Foreign trade and early industrialisation in the Habsburg Monarchy and the United Kingdom - Two extremes in comparison. Ecological Economics, 70(7), 1280-1288.

Grant, R. (1994). The geography of International Trade. Progress in Human Geography, 18(3), $298-312$

Guerin, S.S. (2006). The Role of Geography in Financial and Economic Integration: A Comparative Analysis of Foreign Direct Investment, Trade and Portfolio Investment Flows. The World Economy, 29(2), 189 - 209.

Haibo, L. (2004). Geo-economics at Work. Beijing Review, 47(45), 3.

Hall, N. (2006). The Liverpool Cotton Market and Cotton Re-exports, c. 1815-1914. Northern History, 43(2), $257-271$.

Herekenrath, M. (2007). Introduction: The Regional Dynamics of Global Transformations. International Journal of Comparative Sociology, 48(2/3), 91 - 105.

Jenkins, R. (2014). Chinese Competition and Brazilian Exports of Manufactures. Oxford Development Studies, 42(3), 395-418.

Kaminski, B., Raballand, G. (2009). Entrepôt for Chinese Consumer Goods in Central Asia: The Puzzle of Re-exports through Kyrgyz Bazaars. Eurasian Geography \& Economics, 50(5), 581 - 590.

Kantar, E., Deviren, B., Keskin, M. (2011). Hierarchical structure of Turkey's foreign trade. Physica A, 390(20), $3454-3476$.

Keišs, S., Grišins, A., Tilta, E., Zvirgzdina, R. (2009). Pārtikas rūpniecība un tās produkcijas eksports. Economic Science for Rural Development. Conference Proceedings, 20, 179 - 186.

Krastiņš, O., Ciemiņa, S. (2003) Statistika. Rīga: LR Centrālā statistikas pārvalde.

Krugman, P. (2009). The Increasing Returns Revolution in Trade and Geography. The American Economic Review, 99(3), 561 - 571. 
Lemoine, F. (2010). Past Successes and New Challenges: China's Foreign Trade at a Turning Point. China \& World Economy, 18(3), 1 - 23.

Mack, R.S., Jacobson, D.S. (1996). The Impact of Peripherality upon trade patterns in the European Union. European Urban and Regional Studies, 4(3), 364 - 369.

Paiders, J. (2008). Kvantitatīvu indikatoru izmantošana reǵionālās attīstības analīzē: Promocijas darba kopsavilkums. Rīga, Latvijas Universitāte

Poon, J.P.H., Thompson, E.R., Kelly, P.F. (2000). Myth of the triad? The geography of trade and investment 'blocs'. Transactions of the Institute of British Geographers, 25(4), 427 - 444.

Rocha, da A., Kury, B., Monteiro, J. (2009). The diffusion of exporting in Brazilian industrial clusters. Entrepreneurship \& Regional Development, 21(5-6), 529 - 552.

Tsygankov, A.P. (2000). Defining state interests after empire: national identity, domestic structures and foreign trade policies of Latvia and Belarus. Review of International Political Economy, $7(1), 101-137$.

\section{Summary}

Paper overlooks an exploration of changes and tendencies in the Latvian international trade of commodities of agricultural, fishery and forestry sectors. This is being done by applying wide range of available statistics and published scientific works.

Export statistical analysis is made utilizing frequency method and explores Latvian export/import most stable and constant markets. General data were acquired from Latvian Central Statistics Board for the period from 2000 till 2016. Main analytical method was Fisher $\varphi$ function.

Analysis shows that a lot of good trades between Latvia and it partners are moving according to some particular laws and tendencies. A strong relation between West-East flows was found. Some commodity categories exhibited North-South tendencies, especially in characterizing the flow of basic foodstuffs. Overall it can be noted that international trade of Latvia in sectors of agriculture, fishery and forestry is proactive and developing into a more EU focused network, though significant influence of post-soviet space economies remains evident. 